\title{
The research of environmental-and-economic risks of the coal mining enterprise impact on water resources
}

\author{
Vladimir Mikhailov ${ }^{1, *}$, Natalia Kudrevatykh $^{1}$, and Tatiana Tyuleneva ${ }^{1}$ \\ ${ }^{1}$ T.F. Gorbachev Kuzbass State Technical University, 650000 Kemerovo, 28 Vesennya st., Russian \\ Federation
}

\begin{abstract}
Coal mining enterprise is a high-tech complex with a significant negative impact on water resources in the form of wastewater discharge. To improving the environmental safety of enterprises having a negative impact on the aquatic ecosystem, it is necessary to detail its features in order to increase the efficiency of environmental management. The article analyzes known approaches to the definition and features of formation of systems of assessing the negative impact on water resources. On the basis of synthesis of theoretical developments of domestic and foreign researchers' study and analysis the actual data of an industrial enterprise authors researched its negative impact on water resources to form a program of effective water protection measures. This researching has practical importance for large industrial enterprises that have a negative impact on water resources for effective environmental management decision-making.
\end{abstract}

\section{Introduction}

Coal mining is one of the most dangerous sectors of real sector of economy that is associated with a wide range of negative effects, one of which is pollution of water resources concerning not only waste-water discharges, but also coarse air pollutants, and "flushing" waste production and consumption, including ones characterized by chemical and biological activity [1-4]. Tightening national environmental legislation and international requirements $[5,6]$ motivate coal mining enterprises to use innovative modern technologies, which are called BAT (best available technologies). Despite of intensification this activity, coal mining enterprises are a potential source of high environmental and economic risks, and this fact requires increasing the efficiency and diversification of management methods [7, 8]. In such circumstances, it is necessary to identify the most significant environmental and economic aspects of negative impact on water resources and their assessment on the basis of developed system of environmental and economic indicators. For large industrial enterprises carrying out a complex of basic, auxiliary and service technological processes, the problem of wastewater discharge is urgent, and determines the feasibility of analyzing this type of negative impact with development of measures to ensure environmental safety.

* Corresponding author: mvg.eohp@kuzstu.ru 


\section{Materials and Methods}

The object of research is a coal mining enterprise as a source of negative impact on the environment in the form of wastewater discharges.

The subject of the research is the system of basic ecological and economic indicators of an enterprise characterizing pollution of water sources, including ecological and economic risks.

Researching is based on domestic and foreign literature about problems of ecological and economic analysis of enterprises that discharge wastewater, with using adequate evaluation indicators. Special attention is paid to researching the dynamics of pollutants discharge as sources of environmental and economic risks. For the purpose of practical implementation assessment methodology, statistical processing of environmental data of the coal mining enterprise on the basis of official reporting forms.

\section{Results and Discussion}

There are many scientific points of view to the formation of a system of indicators characterizing the negative impact on water resources, which depend on the industry enterprise specifics and other factors $[9,10]$.

Researching this enterprise was carried out with the help of a number of environmental and economic indicators, where the central place is occupied by economic damage from negative impact on water resources $\left(\mathrm{ED}_{\mathrm{WR}}\right)$ - economic losses of enterprises caused by negative environmental impact on water sources. At the same time, it is advisable to conduct an independent calculation for each pollutant of water resources with the determination of the most significant component [11-13]. Another important indicator is charge for excess negative impact on water resources $\left(\mathrm{C}_{\mathrm{WR}}\right)$, which compensates for the economic damage caused. To increase the assessment efficiency, the following indicators are calculated: the charge for excess negative impact on water resources, its share in the total amount of charges for negative impact on water resources, and coefficient of compensation for economic damage caused to water resources $\left(C C E D_{W R}\right)$, reflecting the effectiveness of the existing mechanism of environmental payments - formula (1):

$$
\mathrm{CCED}_{\mathrm{WR}}=\mathrm{C}_{\mathrm{WR}} / \mathrm{ED}_{\mathrm{WR}} \text {. }
$$

Additional relative environmental and economic indicators - water damage capacity (WDC) of coal production - formula (2) and water charge capacity (WCC) of coal production - formula (3), characterizing corresponding environmental and economic impacts per 1 ton of coal production:

$$
\mathrm{WDC}=\mathrm{WCC} / \mathrm{PO},
$$

where PO - production output (coal production), tones,

$$
\mathrm{WCC}=\mathrm{C}_{\mathrm{WR}} / \mathrm{PO} \text {. }
$$

In table 1 results of calculation main ecological and economic indicators of the coal mining enterprise are presented [14-16]. 
Table 1. Results of calculation of the main ecological and economic indicators of the enterprise JSC "SUEK-Kuzbass" S.M. Kirov Mine.

\begin{tabular}{|l|c|c|c|c|c|}
\hline \multicolumn{1}{|c|}{ Indicator } & $\mathbf{2 0 1 3}$ & $\mathbf{2 0 1 4}$ & $\mathbf{2 0 1 5}$ & $\mathbf{2 0 1 6}$ & $\mathbf{2 0 1 7}$ \\
\hline $\begin{array}{l}\text { Economic damage from negative impact on } \\
\text { water resources, million rubles }\end{array}$ & 143.89 & 60.49 & 4.72 & 6,30 & 6.39 \\
\hline $\begin{array}{l}\text { Total charge for negative impact on water } \\
\text { resources, thousand rubles }\end{array}$ & 993.5 & 1465.8 & 316.0 & 312.0 & 42.9 \\
\hline $\begin{array}{l}\text { Charge for excess negative impact on } \\
\text { water resources, thousand rubles }\end{array}$ & 949.3 & 1432.1 & 266.0 & 0 & 0 \\
\hline $\begin{array}{l}\text { Charge for negative impact on water } \\
\text { resources share, \% }\end{array}$ & 95.55 & 97.70 & 84.18 & 0 & 0 \\
\hline $\begin{array}{l}\text { Coefficient of compensation for econom- } \\
\text { ic damage caused to water resources, \% }\end{array}$ & 0.69 & 2.42 & 6.69 & 4.95 & 0.67 \\
\hline $\begin{array}{l}\text { Production output (coal production), } \\
\text { thousand tones }\end{array}$ & 3747 & 4198 & 4668 & 5720 & 7177 \\
\hline $\begin{array}{l}\text { Water damage capacity of coal produc- } \\
\text { tion, rubles / tone }\end{array}$ & 38.40 & 14.41 & 1.01 & 1.10 & 0.89 \\
\hline $\begin{array}{l}\text { Water charge capacity of coal produc- } \\
\text { tion, rubles / tone }\end{array}$ & 0.27 & 0.35 & 0.07 & 0.05 & 0.01 \\
\hline
\end{tabular}

From table. 1 it can be seen that the value of $\mathrm{CCED}_{\mathrm{WR}}$ for the period significantly decreased from 143.89 million rubles in 2013 to 6.39 million rubles in 2017 . The analysis of $\mathrm{C}_{\mathrm{WR}}$ shows a sharp decline in the indicator-from 1465.8 thousand rubles in 2014 to 42.9 thousand rubles in 2017. Charge for excess negative impact on water resources and its share in the total amount of charges change "nonlinearly".

To assess the compensation function of charge for negative impact on water resources, $\mathrm{CCED}_{\mathrm{WR}}$ has great importance, and its value was maximum in 2015 (6.69\%), and then it decreased to $0.67 \%$ in 2017 .

Improving adequacy of the assessment can be implemented with indicators WDC and WCC coal production. WDC has a maximum value in 2013 - 38.40 rubles/tone, and then a sharp decline begins to 0.89 rubles/tone, which may be characterized as a positive trend. In terms of WCC a similar situation is observed - a decrease of value from 0.35 rubles/tone in 2014 to 0.01 rubles/tone in 2017.

The analysis of ecological and economic indicators of negative impact of water resources requires a more detailed researching pollutants as a source of environmental and economic risks.

In Fig. 1 the dynamics of pollutants ' concentration with the largest mass in wastewaters of JSC "SUEK-Kuzbass" S. M. Kirov Mine by quarters taking into account "representatives" of each hazard class (nitrite nitrogen-II, nitrate nitrogen-III, sulphates-IV, suspended substances - without class of danger).

From Fig. 1 it can be seen that quarterly values of pollutant concentrations differ significantly. In particular, the maximum value of nitrite nitrogen is observed in the 2nd quarter of $2014(0.0509 \mathrm{t})$ and its minimum one is done in the 4th quarter of $2017(0.0042 \mathrm{t})$. Also, a large range of values takes place for sulfates, respectively it is $83.34 \mathrm{t}$ and $12.78 \mathrm{t}$. This situation is observed in the implementation of environmental policy of the enterprise associated with the technological process of coal mining. 

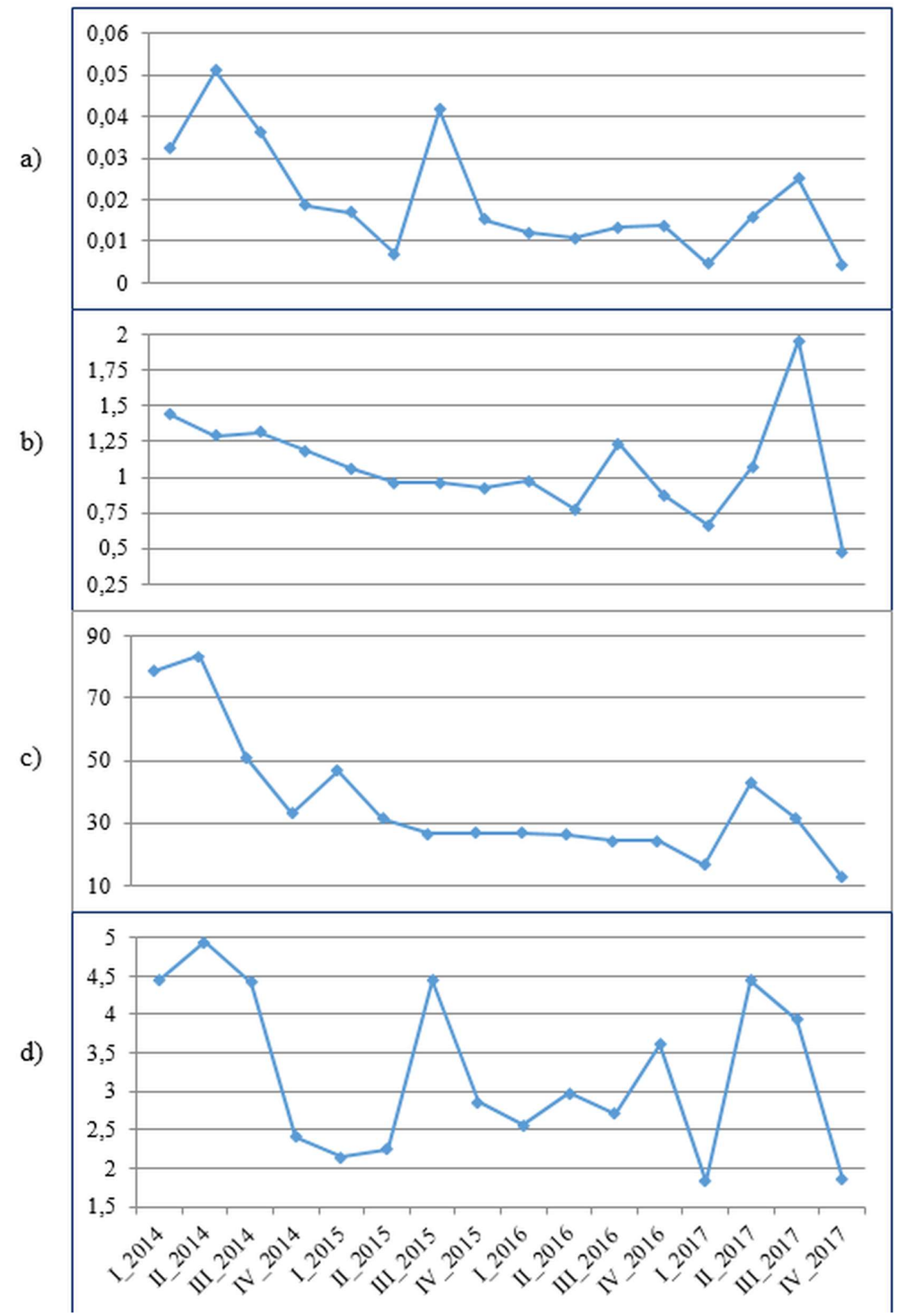

Fig. 1. Dynamics of pollutants' concentration with the largest mass in wastewaters of JSC "SUEKKuzbass" S. M. Kirov Mine by quarters: a) - nitrite nitrogen, b) - nitrate nitrogen, c) - sulfates, d) suspended solids. 
A wide range of pollutant mass values requires an analysis of potential environmental and economic risks and it can be performed statistically [17-21] on the basis of checking the data sample for homogeneity. For this purpose it is necessary to estimate maximum, minimum and average values of the characteristic $\left(x_{\max }, x_{\min }\right.$ и $\left.x_{c p}\right)$, scope of variation $(\mathrm{R})$, variance $\left(\sigma^{2}\right)$, the standard deviation $(\sigma)$ and variation coefficient $(V)$.

Table 2. Main statistical indicators of environmental and economic risks assessment for selected pollutants contained in wastewater of JSC "SUEK-Kuzbass" S. M. Kirov Mine

\begin{tabular}{|c|c|c|c|c|c|c|c|}
\hline Pollutant & $\boldsymbol{x}_{\max }, \mathbf{t}$ & $\boldsymbol{x}_{\boldsymbol{m i n}}, \mathbf{t}$ & $\boldsymbol{R}, \mathbf{t}$ & $\boldsymbol{x}_{\boldsymbol{c} \boldsymbol{}, \mathbf{t}}$ & $\sigma^{\mathbf{2}}$ & $\boldsymbol{\sigma , t}$ & $\boldsymbol{V}$ \\
\hline Nitrite nitrogen & 0.0509 & 0.0042 & 0.0467 & 0.0199 & 0.0002 & 0.0132 & 0.66 \\
\hline Nitrate nitrogen & 1.9541 & 0.4812 & 1.4729 & 1.0722 & 0.1105 & 0.3324 & 0.31 \\
\hline Sulfates & 83.34 & 12.78 & 70.56 & 36.39 & 376.88 & 19.41 & 0.53 \\
\hline $\begin{array}{c}\text { Suspended sol- } \\
\text { ids }\end{array}$ & 4.9465 & 1.8271 & 3.1194 & 3.2368 & 1.0632 & 1.0311 & 0.32 \\
\hline
\end{tabular}

From table. 2 it can be seen that values of variation coefficient for these pollutants are very high, and characterize a significant probability of environmental and economic risks. For example, obtained value $V$ for nitrite nitrogen $(0.66)$ exceeds standard one $(0.25)$ by more than 2 times, and it determines the importance of researching causes of this situation. In general obtained $V$ values show the need for a detailed analysis of significant range of these pollutants` quarterly values.

\section{Conclusion}

The researching allows us to draw the following conclusions:

- known approaches to the formation of a system of indicators characterizing the negative impact on water resources are analyzed;

- absolute and relative ecological and economic indicators for assessment negative impact of coal mining enterprise on water resources are proposed;

- calculation and interpretation of ecological and economic indicators of negative impact of coal mining enterprise on water resources for the purpose of preparation of management decisions aimed at ensuring environmental safety are carried out.;

- graphs of the dynamics pollutants of each hazard class` quarterly values according to the actual data of the enterprise are constructed;

- statistical analysis of changes in polluting water resources selected substances`quarterly values to assess potential environmental and economic risks and make environmentally safe management decisions is carried out.

\section{References}

1. M. Tyulenev, Y. Lesin, E. Tyuleneva, E. Murko, E3S Web of Conferences, 15, 02003 (2017)

2. N.M. Kachurin, V. I. Efimov, S.A. Vorobev, Gornyi Zhurnal, 9, 138-142 (2014)

3. M. Tyulenev, S. Markov, E. Makridin, Y. Lesin, V. Gogolin, E3S Web of Conferences, 105, 02022 (2019)

4. M. Cehlár, P. Varga, Z. Jurkasová, M. Pašková, Acta Montanistica Slovaca, 15: SPECIAL ISSUE 2, 132-138 (2011) 
5. M. Cehlár, L. Mihok, Theoretical and Empirical Researches in Urban Management, 8:4, 60-72 (2013)

6. V.M. Tumin, A.G. Koryakov, E.P. Nikiforova, World Applied Sciences Journal, 25:6, 645-649 (2013)

7. V.N. Burkov, I.V. Burkova, Game Theory and Application, 17, 17-36 (2015)

8. G.A Ugolnitskii, A.B. Usov, Automation and Remote Control. 70:5, 897-906 (2009)

9. E.A. Tretyakova, World Applied Sciences Journal, 25:5, 756-759 (2013)

10. O.V. Kosolapov, M.N. Ignatyeva, A.A. Litvinova, Economy of Region, 1, 158-166 (2013)

11. G.M. Mkrtchyan, T.O. Tagaeva, Yu.O. Tsvelodub, World of Economics and Management, 17:1, 57-69 (2017) (In Russ.)

12. A.S. Tulupov, Gornyi Zhurnal, 8, 61-65 (2017)

13. B.N. Porfiryev, A.S. Tulupov, Studies on Russian Economic Development, 28:6, 600607 (2017)

14. V.G. Mikhailov, T.V. Kiseleva, V.A. Karasev, G. S. Mikhailov, V.A. Skukin, IOP Conf. Ser.: Earth Environ. Sci., 66:1, 012008 (2017)

15. V. Mikhailov, T. Kiseleva, S. Bugrova, A. Muromtseva, Ya. Mikhailova, E3S Web of Conf., 21, 02004 (2017)

16. V.G. Mikhailov, S.M. Bugrova, Yu.S. Yakunina, A.K. Muromtseva, Ya.S. Mikhailova, Ugol, 9, 106-111 (2019)

17. V.P. Avdeev, V. N. Burkov, T.V. Kiseleva, Automation and Remote Control, 62:10, 1645-1650 (2001).

18. V.P. Avdeev, V.N. Burkov, T.V. Kiseleva, Avtomatika i Telemekhanika, 10, 118-125 (2001)

19. I.A. Ageev, V.N. Burkov, V.I. Zinchenko, T.V. Kiseleva, Automation and Remote Control, 66:6, 995-1002 (2005)

20. A. Pimonov, E. Raevskaya, T. Sarapulova, E3S Web of Conf., 15, 01021 (2017)

21. M. Cehlár, J. Janočko, Z. Šimková, T. Pavlik, M. Tyulenev, S. Zhironkin, M. Gasanov, Resources, 8:1, 21 (2019) 